\title{
Product Development and PLM performance measures: a multiple-case study in the fashion industry
}

\author{
Elisa d'Avolio, Romeo Bandinelli, Rinaldo Rinaldi \\ Department of Industrial Engineering, University of Florence, Florence, Italy \\ elisa.davolio@unifi.it \\ romeo.bandinelli@unifi.it \\ rinaldo.rinaldi@unifi.it
}

\begin{abstract}
Performance measurement represents one of the key lever to increase business competitiveness. Fashion companies are characterized by the centrality of products, so development and engineering should be monitored and controlled through proper performance measures. The goal of the entire study is to discuss how performance measurement is able to address and sustain the product development process within the fashion supply chain, considering also the involvement of PLM. A case study analysis has been conducted to select and validate the main measures related to product development and PLM.
\end{abstract}

Keywords: Performance Measurement; Product Development process; Product Lifecycle Management; PLM; Fashion industry.

\section{Introduction}

The importance of performance measurement was first acknowledged a long time ago but, as the years have gone by, Supply Chain (SC) complexity has taken over. The aim of the present study is to highlight the importance of performance monitoring with a special focus on the product development process.

Performance measurement is a cross department practice, which should support and control the overall set of processes within the SC: product development (PD) is just one of them, but it becomes strategic for particular industries as in the Fashion business environment.

The product and its progress are key features for a fashion company that is trying to compete on quality and time-to-market.

From concept to production, the leading role is played by products: each season several items are proposed; depending on the market segment that the company choose to satisfy, the number of new products compared to the "carry over" may vary. Lots of collection, departments and people are involved so that measuring performance is a strategic imperative.

Nevertheless, the growing amount of information related to the product is triggering the importance of proper Information and Communication Technologies (ICTs) supporting PD. The Product Lifecycle Management (PLM), well known in the 
manufacturing industry from almost two decades, is spreading also in the fashion industry. An inner circle of PLM vendors is proposing ad hoc solutions: they are fitting the requirements of fashion companies, more and more complex in terms of data management.

Performance measurement is also including PLM on its evaluations, as a system that has to be reliable in order to allow users to develop collections and that is producing measurable benefits.

The goal of the entire study is to discuss how performance measurement is able to address and sustain the PD process within the fashion $\mathrm{SC}$, considering also the involvement of PLM.

A case study analysis has been performed to compare literature review results, mostly related to the manufacturing industry, with empirical evidences.

The paper is organized as follows: the second section describes the main literature about PD Key Performance Indicators (KPIs); in the third section, the methodology is presented and in the fourth section the main results are analyzed. The paper concludes with several remarks and future challenges.

\section{Literature review}

Performance measurement is a largely debated topic within scientific literature, since the 90's, but the number of papers which deal with PD, as a specific process within SC, is just a small subset. The latter becomes smaller and smaller as the focus shifts to the fashion industry.

In order to study the large number of performance measures available, researchers have categorized them. A framework has been proposed for performance measurement based on three main components to manufacturing SC success: resources, output and flexibility [1]. Another classification based on the main SC performance measures distinguishes between innovativeness, information accuracy and timeliness [2]. Other approaches include SC management models ([3], [4]) or Balanced Scorecard for SC management evaluation [5]. Just a little part of the analyzed literature ([6], [7], [8]) is focused on the fashion industry: the authors analyze particular measures, mostly related to Marketing and Retail needs or to sustainability issues.

The topic of PD performance measures is still underexplored in literature. PD activity is intrinsically intangible, non-routine, uncertain and organizationally complex. These special characteristics combine to make PD performance measurement especially challenging.

According to [9], a given performance measure is characterized by the combination of four aspects: its managerial purpose, object of interest, measurement forms and linkages with other metrics. The dimensions and elements of these four characteristics make up a formative framework defining the space of conceivable PD metrics.

More industry-specific papers ([10], [11]) describe how PD can be better controlled for manufacturing and high tech companies. A research [10] has led to the development of the performance measurement for product development (PMPD) 
methodology to guide managers in the use of performance measures to improve decision-making during the PD process.

According to [11] several PD tools and techniques (for example, DOE,

FMEA/DFMEA, and supplier involvement) have a significant effect on the overall performance of $\mathrm{PD}$ and on a number of performance indicators, but their utilization is not especially high.

The Information Technology (IT) business value refers to the organizational performance impacts of IT, including productivity enhancement, profitability improvement, cost reduction, competitive advantage, inventory reduction, and other measures of performance [12]. The effect of investments in Enterprise Systems (ES) on long-run stock price and profitability performance have been reported by [13]: the authors highlight the improvements in profitability by adopters of ERP systems.

[14] propose a solution, based on the key performance indicator (KPI) method, for evaluating the benefits introduced by the adoption of a PLM tool in a manufacturing company. The study sheds some light on the need to identify a set of significant indicators that could synthesize the company behavior.

The literature analysis has not allowed the authors to gather information about PD and PLM performance measures in the fashion industry. In order to reach the goal of the present study and to fill the literature gap, several case studies have been conducted.

\section{Research approach}

The research has been inspired by several projects carried out in fashion companies that are recognizing the importance of performance measurement and its role in the PD process.

The starting point has been a literature review, that has allowed the authors to learn from other studies and compare metrics and viewpoints about KPIs classifications.

Consequently, the research has focused on two main areas: PD KPIs and PLM KPIs; the first one is more process-oriented and the second one more IT-oriented, but both are strictly linked to product development.

Given the different approaches to performance measurement and involvement of information technologies, two parallel case studies have been conducted.

Case study has been chosen to investigate the choices in terms of approach to performance management in Italian fashion companies. This methodology is adopted to gain a more in-depth understanding of the dynamics present within single settings [15]. In order to increase confidence in the findings, multiple-case sampling has been used [16].

For the first area of interest, i.e. PD KPIs, a questionnaire has been designed and administrated to six fashion companies, as shown in Table 1. The sample has been classified basing on:

- The activities conducted in-house or outsourced: it is a driver of the importance that the business assigns to several tasks. 
- The main product represents the core business and reveals the companies' critical success factors (CSFs): quality seems to be more strategic for leather goods and timing for ready-to-wear (RTW).

- $\quad$ The companies' sizes in terms of stock keeping units (SKUs)

- The market segment the companies belong to

The firms are international brands with at least a business unit in Italy. The half part of the sample is composed of big high fashion (luxury) companies, producing leather goods (shoes, bags, accessories) or made to measure garments. While, other three companies are medium lines selling ready to wear (pants, skirts, sweaters, dresses) and outerwear (jackets, trench, winter coats). The authors have decided to involve companies paying huge attention to the PD process, which is always conducted in-house. The interviewees were Managers of the finance, product development and production departments.

Table 1. Case studies conducted for PD KPIs

\begin{tabular}{lllll}
\hline Cases & In-house activities & Main Product & $\mathbf{N}^{\circ}$ SKU & Market segment \\
\hline Case 1 & All & Leather goods & $>1000$ & $\begin{array}{l}\text { Luxury } \\
\text { Diffusion }\end{array}$ \\
Case 2 & $\begin{array}{l}\text { Distribution, product } \\
\text { development }\end{array}$ & Ready-to-wear & $>1000$ & Diffusion \\
Case 3 & $\begin{array}{l}\text { Distribution, retail, product } \\
\text { development }\end{array}$ & Ready-to-wear & $500-1000$ & Diffusion \\
Case 4 & All but production & Outerwear & 100 & Prêt-à-porter \\
Case 5 & All & Leather goods & $>1000$ & Luxury \\
Case 6 & All & Made to measure & $>1000$ & \\
\hline
\end{tabular}

For the second area of interest, i.e. PLM KPIs, only IT and Data Managers have been involved because of their higher knowledge about enterprise systems, configurations and interfaces. This analysis required a more detailed study, given the lack of literature researches and the complexity of the topic.

Two big high fashion companies, representing internationally iconic brands and selling mainly leather goods, participated to this second stage of the research (Table 2 ). They manage in-house the great part of the business processes and have implemented the same fashion-specific PLM solution, which is properly integrated with other systems.

Table 2. Case studies conducted for PLM KPIs

\begin{tabular}{llcccc}
\hline Cases & In-house activities & Main Product & $\mathbf{N}^{\circ}$ SKU & $\begin{array}{l}\text { Market } \\
\text { segment }\end{array}$ & $\begin{array}{l}\text { PLM } \\
\text { implementation }\end{array}$ \\
\hline Case 1 & All & Leather goods & $>1000$ & Luxury & Since 3 years \\
Case 2 & All but production & Leather goods & $>1000$ & Luxury & Since 2 years \\
\hline
\end{tabular}

In Figures 1 and 2 the different methodologies have been represented. The research that has led to the acknowledgement of PD KPIs and performance measurement 
approach has been a validation of already known, but more industry-specific, performance measures.

Instead, the research that has led to the acknowledgement of PLM KPIs has been introduced by a generic examination of PLM KPIs but the biggest contribution has come from meetings dedicated to IT issues.

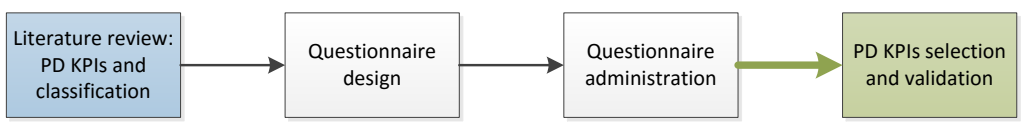

Fig. 1. Methodology adopted for PD KPIs

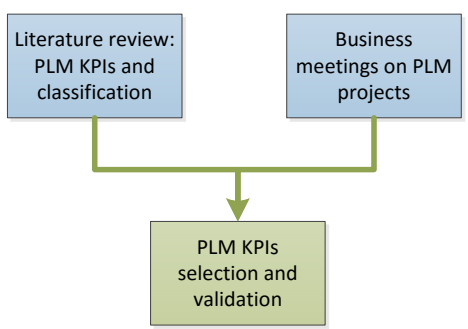

Fig. 2. Methodology adopted for PLM KPIs

\section{Discussion}

In order to investigate about PD performance measures in the fashion industry, a "draft" list of KPIs has been identified from the literature review. The interviewees were asked to examine this list and to specify the degree of importance of the indicator, according to a 1-4 scale ( $1=$ Not important; 2=Low importance; $3=$ Important; $4=$ Very important).

Moreover, interviewees detailed for each measure the typology of ICT tool (e.g. PDM, PLM, Business Intelligence, ERP) adopted in order to store and monitor KPIs.

In table 3 the validated list of PD KPIs is detailed and classified basing on resource, cost and time measures. The last column of the table, counts the number of cases adopting each KPI: resource and cost KPIs are the most adopted by the companies interviewed, in particular prototype and sample annual costs and HR employment in different departments.

Each case study described in Table 1, has its own way to manage those KPIs.

The first case is a high fashion company that prefers to monitor production KPIs more than PD ones. Just few PD measures are controlled and they have a low importance. PLM is still not implemented, but a PDM provides the information to manage KPIs.

The second case is a RTW company that pays huge attention to PD, also for time KPIs. A Business Intelligence solution is able to trace data about performance measures, but the firm is not ready to a full PLM implementation. 
The third case is a RTW diffusion company that controls other SC KPIs and has a holistic approach to performance measurement. It monitors all the KPIs listed in Table 3 and is using a PDM solution.

The fourth case is an outerwear company that is not measuring lots of KPIs among the PD measures: it prefers to monitor just cost KPIs, so it has a financial approach to performance measurement. These are controlled through a Business Intelligence solution.

The fifth and the sixth cases have in common the strategic goal to sell premium quality products: leather goods (fifth case) and ties, scarves and made-to-measure garments for men (sixth case). PD is definitely their core business, so they measure many of the listed KPIs, more than measures related to other SC processes (sourcing, production, distribution, etc.). They strongly believe in handcrafted tradition and are still not able to innovate through PLM solutions.

This first step of the research has been particularly interesting because interviewees have validated the list of performance measures and acknowledged the importance of proper tools supporting PD management.

Table 3. Classification of PD KPIs

\begin{tabular}{|c|c|c|c|c|}
\hline KPI ID & $\begin{array}{l}\text { KPI } \\
\text { classification }\end{array}$ & PD KPIs & Description & $\begin{array}{l}\text { KPIs } \\
\text { adoption } \\
\text { (0-6 cases) }\end{array}$ \\
\hline PD-1 & Resource & Human resources & Average number of HR employed in the & 4 \\
\hline PD-2 & Resource & $\begin{array}{lr}\text { Human } & \text { resources } \\
\text { (FTE) - Product }\end{array}$ & $\begin{array}{l}\text { Average number of HR employed in the } \\
\text { PD Department }\end{array}$ & 5 \\
\hline PD-3 & Resource & $\begin{array}{l}\text { Development } \\
\text { Human resources } \\
\text { (FTE) - Modelling }\end{array}$ & $\begin{array}{l}\text { Average number of HR employed in the } \\
\text { Modeling Department }\end{array}$ & 5 \\
\hline PD-4 & Resource & $\begin{array}{l}\text { Human resources } \\
\text { (FTE) - Prototyping }\end{array}$ & $\begin{array}{l}\text { Average number of HR employed in the } \\
\text { Prototyping Department }\end{array}$ & 5 \\
\hline PD-5 & Resource & $\begin{array}{l}\text { Number of fabrics } \\
\text { (FW) }\end{array}$ & $\begin{array}{l}\text { Average number of fabrics adopted } \\
\text { during the fall-winter season }\end{array}$ & 3 \\
\hline PD-6 & Resource & Number of fabrics (SS) & $\begin{array}{l}\text { Average number of fabrics adopted } \\
\text { during the spring-summer season }\end{array}$ & 3 \\
\hline PD-7 & Resource & Number of colors (FW) & $\begin{array}{l}\text { Average number of colors developed } \\
\text { during the fall-winter season }\end{array}$ & 3 \\
\hline PD-8 & Resource & Number of colors (SS) & $\begin{array}{l}\text { Average number of colors developed } \\
\text { during the spring-summer season }\end{array}$ & 3 \\
\hline PD-9 & Resource & $\begin{array}{l}\text { Number of planned } \\
\text { models (briefing) }\end{array}$ & $\begin{array}{l}\text { Average number of models planned } \\
\text { during the briefing }\end{array}$ & 3 \\
\hline PD-10 & Resource & $\begin{array}{l}\text { Number of final models } \\
\text { (briefing) }\end{array}$ & $\begin{array}{l}\text { Average number of actual models } \\
\text { calculated during the briefing }\end{array}$ & 4 \\
\hline PD-11 & Resource & $\begin{array}{l}\text { Product typology }(\% \\
\text { carry over and new } \\
\text { models) }\end{array}$ & $\begin{array}{l}\text { Percentage of carry over and new } \\
\text { products within a season }\end{array}$ & 3 \\
\hline PD-12 & Cost & Prototypes annual cost & $\begin{array}{l}\text { Average annual cost to produce } \\
\text { prototypes }\end{array}$ & 6 \\
\hline PD-13 & Cost & Samples annual cost & Average annual cost to produce samples & 6 \\
\hline PD-14 & Cost & $\begin{array}{l}\text { Prototype } \\
\text { Cost/Production Cost }\end{array}$ & $\begin{array}{l}\text { Ratio between the average prototype cost } \\
\text { and the average production cost }\end{array}$ & 3 \\
\hline PD-15 & Cost & $\begin{array}{l}\text { Sample } \\
\text { Cost/Production Cost }\end{array}$ & $\begin{array}{l}\text { Ratio between the average sample cost } \\
\text { and the average production cost }\end{array}$ & 2 \\
\hline PD-16 & Cost & $\begin{array}{l}\text { Fitting costs/ } \\
\text { Production cost }\end{array}$ & $\begin{array}{l}\text { Ratio between the average fitting cost and } \\
\text { the average production cost }\end{array}$ & 1 \\
\hline PD-17 & Time & $\begin{array}{l}\text { Compliance } \\
\text { Marketing Brief }\end{array}$ & $\begin{array}{l}\text { Ratio between the average number of } \\
\text { models planned and the average number } \\
\text { of actual models calculated during the } \\
\text { briefing }\end{array}$ & 3 \\
\hline PD-18 & Time & $\begin{array}{l}\text { Compliance with the } \\
\text { product engineering } \\
\text { schedule (FW) }\end{array}$ & $\begin{array}{l}\text { Ratio between the actual time and the } \\
\text { planned time to engineer products during } \\
\text { the fall-winter season }\end{array}$ & 2 \\
\hline PD-19 & Time & $\begin{array}{l}\text { Compliance with the } \\
\text { product engineering } \\
\text { schedule (SS) }\end{array}$ & $\begin{array}{l}\text { Ratio between the actual time and the } \\
\text { planned time to engineer products during } \\
\text { the spring-summer season }\end{array}$ & 2 \\
\hline PD-20 & Time & $\begin{array}{l}\text { Number of fitting } \\
\text { sessions (FW) }\end{array}$ & $\begin{array}{l}\text { Average number of fitting session during } \\
\text { the fall-winter season }\end{array}$ & 1 \\
\hline PD-21 & Time & $\begin{array}{l}\text { Number of fitting } \\
\text { sessions (SS) }\end{array}$ & $\begin{array}{l}\text { Average number of fitting session during } \\
\text { the spring-summer season }\end{array}$ & 1 \\
\hline
\end{tabular}


Coming to the second part of this research, i.e. investigating PLM performance measures in the fashion industry, the main results are listed in the tables 4-8.

KPIs have been assessed basing on:

- a performance measure classification: time, cost, quality, flexibility and infrastructure KPIs. The majority of PLM KPIs are time-based measure because one of the main challenges in PLM implementation is the reduction of time-to-market and time to develop products.

- a process classification: data management, data configuration, printing, import/export configuration. PLM solutions allow to manage data from the user interface (create styles, colors, materials. etc.) or to configure data in proper settings (define templates, attributes, behaviors on copy, validation rules, etc.).

Other IT solutions and layers could be interfaced to PLM, as printing layers, ERP, MRP and PDM. When PLM is the master data for PD, an import/export job scheduling is available through stored procedures or proper tables.

During business meetings, the following KPIs have been identified and validated, explaining the general meaning and the background.

Time measures are mainly related to actions taken by users in day-by-day data management, developing styles and materials. The latter two represent the core business objects (BOs) for a fashion PLM solutions. Users usually manage properties within single BOs or aggregated information in table views, including data of more departments (shoes, bags, accessories, etc.) and more collections. One of the key features of a flexible PLM is the opportunity to introduce expressions calculating costs or ensuring data validation: the elapsed processing time may vary depending on the number of objects involved and on the complexity of the expression. Users also need to export data from PLM and to send it to suppliers: data packages, bill of materials (BOMs), quotes reports have to be printed in pdf files. The performances of the printing process have been also included because sending product information to factories is fundamental for companies which outsource production, as long as printing massive data (e.g. all the BOMs by collection) may take long times. Export batches are the protagonists of data exchange with business enterprise tools. They are scheduled through proper jobs and have to be as fast as possible to ensure data updates and real time collaboration. Other information are imported in PLM, as material codes, and their availability is also remarkable.

Cost measures refers to issues noticed by users, that could be bugs or simple needs for training, requiring an application maintenance service. Costs related to the upgraded release and to an additional customization should be taken into account.

Quality measures represent authentic drivers to select a business specific PLM, given the enterprise architecture structure. The number of aggregated data to be exported to ERP and the frequency of export are strictly dependent on the business environment needs: from four times to once in a day, a company should need to export all the information of more than two seasons.

Flexibility measures could refer to the capability of PLM to support the majority of business processes linked to products. When agile deployment is feasible, the PLM vendor is also able to introduce proper changes to the present configuration and this is a measure of flexibility too.

Finally, infrastructure measures could be seen from the business viewpoint or from the PLM vendor perspective. In the first case, the business needs to understand if it is 
compliant to PLM system requirements and hardware configuration. In the second case, the PLM has to guarantee an adequate number of out of the box (OOTB) business objects and several upgrades, at least for bug fixing reasons.

Table 4. PLM Time KPIs

\begin{tabular}{|c|c|c|c|}
\hline KPI ID & PLM KPIs & Description & Process \\
\hline PLM-1 & $\begin{array}{l}\text { Time to create/copy a } \\
\text { style/material }\end{array}$ & $\begin{array}{l}\text { Average time to create a new } \\
\text { style/material or a carry over }\end{array}$ & Data management \\
\hline PLM-2 & Time to create a new BOM & Average time to create a new BOM & Data management \\
\hline PLM-3 & $\begin{array}{l}\text { Time to create/copy a new } \\
\text { BOM item }\end{array}$ & $\begin{array}{l}\text { Average time to create a new BOM } \\
\text { item }\end{array}$ & Data management \\
\hline PLM-4 & Time to create a color library & $\begin{array}{l}\text { Average time to create a seasonal } \\
\text { color library }\end{array}$ & Data management \\
\hline PLM-5 & $\begin{array}{l}\text { Time to issue a supplier } \\
\text { request }\end{array}$ & $\begin{array}{l}\text { Average time to send to suppliers a } \\
\text { technical sheet r containing } \\
\text { information for product } \\
\text { prototyping/sampling }\end{array}$ & Data management \\
\hline PLM-6 & $\begin{array}{l}\text { Time to massively issue } \\
\text { supplier requests }\end{array}$ & $\begin{array}{l}\text { Average time to send to suppliers } \\
\text { more technical sheets containing } \\
\text { information for } \\
\text { prototyping/sampling }\end{array}$ & Data management \\
\hline PLM-7 & $\begin{array}{l}\text { Time to load aggregated } \\
\text { information in table views }\end{array}$ & $\begin{array}{l}\text { Average time required to display } \\
\text { information related to more styles in } \\
\text { a table view }\end{array}$ & Data management \\
\hline PLM-8 & $\begin{array}{l}\text { Processing time for costs } \\
\text { calculations }\end{array}$ & $\begin{array}{l}\text { Average elapsed processing time to } \\
\text { execute an expression related to cost } \\
\text { calculation }\end{array}$ & Data management \\
\hline PLM-9 & Time to print a table view & $\begin{array}{l}\text { Average time to print the } \\
\text { information contained in a table view }\end{array}$ & Printing \\
\hline PLM-10 & Time to print a set of BOMs & $\begin{array}{l}\text { Average time to print the } \\
\text { information contained in a }(\mathrm{BOM})\end{array}$ & Printing \\
\hline PLM-11 & Time to print Data Packages & $\begin{array}{l}\text { Average time to generate and print a } \\
\text { Data Package containing more sheets }\end{array}$ & Printing \\
\hline PLM-12 & $\begin{array}{l}\text { Time to export the report of } \\
\text { BOM items to ERP }\end{array}$ & $\begin{array}{l}\text { Average time to run the scheduled } \\
\text { export batch containing information } \\
\text { about styles and the related materials }\end{array}$ & Import/Export configuration \\
\hline PLM-13 & $\begin{array}{l}\text { Time to export the report of } \\
\text { supplier quotes to ERP }\end{array}$ & $\begin{array}{l}\text { Average time to run the scheduled } \\
\text { export batch containing information } \\
\text { about styles and the related quotes }\end{array}$ & Import/Export configuration \\
\hline PLM-14 & $\begin{array}{l}\text { Time to } \text { import } \\
\text { style/material/suppliers codes } \\
\text { from PDM }\end{array}$ & $\begin{array}{l}\text { Average time to run the scheduled } \\
\text { import job containing information } \\
\text { about styles/materials/suppliers }\end{array}$ & Import/Export configuration \\
\hline PLM-15 & $\begin{array}{l}\text { Time to download reports } \\
\text { imported in PLM }\end{array}$ & $\begin{array}{l}\text { Average time to download a single } \\
\text { report imported into PLM }\end{array}$ & Import/Export configuration \\
\hline
\end{tabular}


Table 5. PLM Cost KPIs

\begin{tabular}{llll}
\hline KPI ID & PLM KPIs & Description & Process \\
\hline PLM-16 & $\begin{array}{l}\text { Number of PLM incidents } \\
\text { (monthly) }\end{array}$ & $\begin{array}{l}\text { Average number of system issues } \\
\text { noticed by users }\end{array}$ & Data management \\
PLM-17 & $\begin{array}{l}\text { Cost to implement a custom } \\
\text { configuration }\end{array}$ & $\begin{array}{l}\text { Average cost to implement medium- } \\
\text { high configuration based on business } \\
\text { requirements }\end{array}$ & $\begin{array}{l}\text { Refers to the capability of the user } \\
\text { interface to be simple and friendly } \\
\text { Pverage cost to upgrade the system Datanation } \\
\text { to the new release }\end{array}$ \\
PLM-19 & Data searching time & Cost to upgrade release version & Datiguration \\
\hline
\end{tabular}

Table 6. PLM Quality KPIs

\begin{tabular}{|c|c|c|c|}
\hline KPI ID & PLM KPIs & Description & Process \\
\hline PLM-20 & $\begin{array}{l}\text { Number of seasonal data to be } \\
\text { exported to ERP }\end{array}$ & $\begin{array}{l}\text { Average number of data exportable } \\
\text { to ERP related to a season (including } \\
\text { several collections and styles) }\end{array}$ & $\begin{array}{l}\text { Import/Export } \\
\text { configuration }\end{array}$ \\
\hline PLM-21 & $\begin{array}{l}\text { Frequency of master data } \\
\text { export to ERP }\end{array}$ & $\begin{array}{l}\text { Average frequency of master data } \\
\text { export from PLM to ERP }\end{array}$ & $\begin{array}{l}\text { Import/Export } \\
\text { configuration }\end{array}$ \\
\hline PLM-22 & Loop monitoring \& controlling & $\begin{array}{l}\text { Availability of a tool to control and } \\
\text { remove potential loops }\end{array}$ & Data configuration \\
\hline PLM-23 & PLM system scalability & $\begin{array}{l}\text { Refers to the PLM capability to } \\
\text { increase its performance to } \\
\text { accommodate the resources growth }\end{array}$ & Data configuration \\
\hline PLM-24 & Information tracking & $\begin{array}{l}\text { Refers to the PLM capability to } \\
\text { allow product information } \\
\text { traceability and history }\end{array}$ & Data configuration \\
\hline
\end{tabular}

Table 7. PLM Flexibility KPIs

\begin{tabular}{llll}
\hline KPI ID & PLM KPIs & Description & Process \\
\hline PLM-25 & Number of user profiles & $\begin{array}{l}\text { Average number of users configurable } \\
\text { in PLM }\end{array}$ & $\begin{array}{l}\text { Data } \\
\text { configuration }\end{array}$ \\
PLM-26 & $\begin{array}{l}\text { PLM footprint in the fashion } \\
\text { company }\end{array}$ & $\begin{array}{l}\text { Percentage of business processes } \\
\text { supported by PLM }\end{array}$ & $\begin{array}{l}\text { Data management } \\
\text { Pefers to the PLM ability to adapt to Data } \\
\text { possible or future changes in business configuration } \\
\text { PLM-27 }\end{array}$ \\
\hline
\end{tabular}


Table 8. PLM Infrastructure KPIs

\begin{tabular}{|c|c|c|c|}
\hline KPI ID & PLM KPIs & Description & Process \\
\hline PLM-28 & $\begin{array}{l}\text { Number of upgraded releases } \\
\text { per two-year period }\end{array}$ & $\begin{array}{l}\text { Number of releases provided by the } \\
\text { PLM vendor }\end{array}$ & $\begin{array}{l}\text { Data } \\
\text { configuration }\end{array}$ \\
\hline PLM-29 & $\begin{array}{l}\text { Business compliance to PLM } \\
\text { software requirements }\end{array}$ & Considers client system requirements & $\begin{array}{l}\text { Data } \\
\text { configuration }\end{array}$ \\
\hline PLM-30 & $\begin{array}{l}\text { Business compliance to PLM } \\
\text { hardware requirements }\end{array}$ & $\begin{array}{l}\text { Considers database and application } \\
\text { server hardware configuration }\end{array}$ & $\begin{array}{l}\text { Data } \\
\text { configuration }\end{array}$ \\
\hline PLM-31 & $\begin{array}{l}\text { Number of OOTB Business } \\
\text { Objects }\end{array}$ & $\begin{array}{l}\text { Average number of Business Objects } \\
\text { implemented out-of-the-box in PLM }\end{array}$ & $\begin{array}{l}\text { Data } \\
\text { configuration }\end{array}$ \\
\hline
\end{tabular}

The case studies related to PLM performance measures are particularly meaningful because through the listed KPIs it is possible to finalize an all-embracing PLM assessment and, in detail, to:

- compare different PLM solutions

- $\quad$ compare different versions of the same PLM solution

- compare the data management before/after PLM

- compare different configurations of the same PLM solution (in different companies)

While time KPIs are more industry specific, the remaining are more generic performance measures that could be monitored in any PLM project.

This analysis about PLM performance measures differs from the one related to PD KPIs because an evaluation of the measures within the case studies is still missing. Nevertheless, the companies interviewed have demonstrated how strategic business alignment, process-based PLM design and reduction of customizations are critical success factors for fashion firms implementing a PLM solution.

One of the main improvements consists in changing the way to work and PLM enables this change. To better perform, a company has to focus on process enhancement and then on system change, avoiding to customize the solution to support old processes.

Software customizations entail an effort in terms of costs and time; PLM is also more expensive to maintain and less flexible for future integrations. Choosing OOTB configuration is one the right ways to improve the overall set of PLM performances.

\section{Conclusions and future work}

This research has the objective to underline the importance of PD performance measures for fashion companies. A preliminary literature review has introduced the authors to KPIs analysis and classification, concerning both PD process and PLM. A lack of studies in the fashion industry has been noticed and a case study analysis has been performed.

The authors have tried to provide a comprehensive view of the measures related to product lifecycle, starting from process to data management. PD KPIs has been 
validated with each company interviewed and a qualitative estimation of the measures has demonstrated the chosen approach to performance measurement.

PLM KPIs has been identified through a more complex and deep analysis with process owners and ICT managers. This analysis represents a preliminary stage to evaluate PLM performance within fashion companies, through proper industryspecific KPIs.

The interviews have allowed the authors to describe in a qualitative manner the best way to perform PD process and PLM implementation. Future researches will be conducted to achieve a quantitative assessment of PD and PLM measures, in order to ensure generalizability of results.

\section{References}

1. Beamon B. M.: Measuring supply chain performance. International Journal of Operations \& Production Management 19 (1999)

2. Cai J. et al.: Improving supply chain performance management: a systematic approach to analyze iterative KPI accomplishment. Elsevier B.V. (2008).

3. Gunasekaran A. et al:: A framework for supply chain performance measurement. International journal of production economics (2004).

4. Sheperd C. and Gunter H.: Measuring supply chain performance: current research and future directions. International journal of productivity and performance management, 55 (2004).

5. Bhagwat R. and Sharma M.K.: Performance measurement of supply chain management: a balance scorecard approach. Computers \& Industrial Engineering (2007).

6. Mattila $\mathrm{H}$. et al., Retail performance measures for seasonal fashion, Journal of fashion marketing and management vol.6 No.4, 2002.

7. Moore, M., Fairhurst, A.: Markerting capabilities and firm performance in fashion retailing. Journal of Fashion Marketing and Management, 7, 4, 386-397 (2003).

8. de Brito, M.P. et al.: Towards a sustainable fashion retail supply chain in Europe: Organisation and performance. International Journal of Production Economics 114, 534-553 (2008).

9. Tatikonda, M. V.: Product development performance measurement. Handbook of new product development management, 199 (2008).

10. Driva, H., Pawar, K. S. and Menon, U.: Measuring product development performance in manufacturing organisations. International Journal of Production Economics 63, 147-159 (2000).

11. Tsu-Ming, Y., Pai, F-Y. and Yang, C-C.: Performance improvement in new product development with effective tools and techniques adoption for high-tech industries. Quality \& Quantity 44, 131-152 (2010).

12. Melville, N., Kraemer, K.and Gurbaxani, V.: Review: Information technology and organizational performance: An integrative model of IT business value. MIS quarterly 28, 283-322 (2004).

13. Hendricks, K.B., Singhal, V.R. and Stratman, J.K.: The impact of enterprise systems on corporate performance: A study of ERP, SCM, and CRM system implementations. Journal of Operations Management 25, 65-82 (2007).

14. Alemanni, M. et al.: Key performance indicators for PLM benefits evaluation: The Alcatel Alenia Space case study. Computers in Industry 59, 833-841 (2008).

15. Yin, R.K.: Case study research: Design and methods. CA: Sage Publication. (1984).

16. Miles, M., and Huberman, A. M.: Qualitative data analysis. Beverly Hills, CA: Sage Publications (1984). 